JAMES SELLMANN

\title{
ON THE MYTH OF COSMOGONY IN ANCIENT CHINA
}

To reconstruct the archaic and classical world view of any culture, one wants to be conscious of one's own personal and cultural biases. In the Euro-American academy it is customary to attempt such a reconstruction through the study of ancient mythology. This has proved fruitful, for example, in Mircea Eliade's study of ancient conceptions of time.' Let me review and take issue with one of the more widely accepted approaches to the study of ancient Chinese culture, an approach that has perhaps been overly influenced by Euro-American academic and methodological biases.

\section{A. THE MYTHIFICATION OF HISTORY - AGAINST REVERSE EUHEMERIZATION}

In the case of China, two major views have developed in interpreting the culture of the archaic Shang (1767-ca. 1040 B.C.E.) and early Western Chou dynasties (1040-770 B.C.E.). These cultural world views presage the development of classical Chou philosophy of the Warring States period (403-221 B.C.E.), also commonly referred to as the pre-Ch'in period because of the fundamental changes that occurred with the $\mathrm{Ch}^{\prime}$ in unification in 221. Perhaps not surprisingly, the generally received interpretation of archaic China proposes that Chinese culture developed along "similar" lines as Indo-European culture, from mythology to philosophy, or as David Hall has described the model of Western development from chaos through mythos to logos. ${ }^{2}$

The second view, which this work represents, is that archaic Chinese religio-philosophy is based on the veneration of historical clan ancestors, and a systematic mythos emerges late in the classical pre-Ch'in period, culminating in the Han dynasty. Chinese culture develops in its own way, distinct from Indo-European culture, without a mythology, as F. Mote has argued. $^{3}$

The received interpretation for the development of Indo-European cultures and philosophy is that they developed highly rational, historical, and naturalistic world views after moving through different forms 
of religion, and more "primitive" modes of expression: mythos, magic, nature worship, and so on. G. W. F. Hegel proposed this general scheme in his historical dialectic of Absolute Spirit which develops through art, is negated by religion, and is finally realized in philosophy.

Max Müller is noted for his nature worship theory which offers an empirical basis through the interpretation of ancient mythology and language to support the claim that "primitive religion" arose out of man's confrontation with a hostile environment. Man's fear and respect for the elements developed into a system of nature worship which in time deified the forces of nature. This polytheism is revealed in the mythology and ritual of "primitive religion" such that the religion is further rationalized into what Müller called a henotheism - a "king/father" god dominates the polytheistic pantheon - either at different seasonal rites or over periods in the historical development of the mythic literature. With higher levels of abstraction, monotheism comes into practice. With further advances in reason, monotheism transforms into monism, and philosophy is born. Müller's analysis certainly has explanatory force for the general development of religio-philosophy found in the Vedas and the Upanishads. It can also be applied to the development of Babylonian culture and philosophy. And Egyptian, Ionian, and Roman culture appear to fit this model equally well. In fact, Francis M. Cornford and others attribute the birth of Ionian philosophy to Thales because he seeks a naturalistic interpretation of the world which opposed the traditional religio-mythical appeal to supernatural forces or gods. Setting aside the question of the adequacy of this "rationalization" of pre-Socratic philosophy, there has been a general tendency in our cross-cultural and historical studies to export our universal indexicals and to see all civilizations as dependent on universal or transcendent principle. When such principles are not readily apparent in other cultures, they are "excavated" or constructed by implication to justify and lend credence to claims that another culture is in fact civilized.

The peculiar and even ironic consideration is that this received interpretation of the development of culture and philosophy is heavily influenced by the archaic mythological world view which it is attempting to explain. Two recurring features of these myths, from the Indus to the Tiber, are: first, a cosmogony which establishes a purpose (telos) for that culture; and secondly, the assumption of the universality of the traditional myth. Archaic myth assumes that its mythos is universally true for the whole world - if other peoples lack similar myths, it is an 
indication of their primitive, uncultured, maybe even non-human status. First, note that the received historical interpretation harbors an implicit teleology in proposing that rational philosophy develops after religion and its primitive superstitious origins in mythical explanation. The modern interpreters of the past, like the ancient myths, attempt to reconstruct the "origin" of our world of philosophy and science in the cosmogonic myths or in their rejection. Second, the received interpretation is believed, necessarily, to have application to all cultures universally, or at least, to all developed "cultures." Although the general pattern of development from myth to philosophy appears to fit the archaic traditions of Persia, India, and the Mediterranean peoples, it does not follow that all archaic cultures display similar developments as Max Müller, Carl Jung, Mircea Eliade, Derk Bodde, and others have proposed.

Contra such generalizations, the anthropologist Clifford Geertz has argued that universalism, especially structuralism, leads to cultural arrogance,${ }^{4}$ and John S. Mbiti has similarly argued against the excessive ethnocentric assumption in Western academic theories which attempt to account for the origin of religion and philosophy, namely, that the West is clearly a higher culture, while most of the so-called third world nations are still in the mythological stage. ${ }^{5}$

This developmental approach "from myth through religion to philosophy" has had wide appeal among academics, and it has been adopted by sinologists, both Chinese and non-Chinese, to explain the development of archaic China. ${ }^{6}$ The problem is that, as has been repeatedly reported, the earliest Chinese records and objects of material culture are relatively devoid of any complex mythology or even individual systematic myths. Especially noticeable in their absence are cosmogonic myths. ${ }^{7}$ This inconvenient lack of systematic myth, however, has not prevented prominent scholars, such as Derk Bodde, from speculating that an archaic mythology existed before the extant ancient literature historicized and humanized the ancient gods. As an example, in explanation of the myths of China merging during the Han dynasty, Bodde's student Charles Le Blanc has proposed that, at least, the myth of Huang Ti developed through three phases. First, there was the original myth of pre-Shang and Shang culture; then, the early and middle Chou peoples historicized the myth; and finally, the late Chou and early Han remythologized Huang Ti. ${ }^{8}$ Because Le Blanc and many others derive much of their interpretation of Chinese mythology from Derk Bodde's "Myths 
of Ancient China," I shall examine this study to make my point that his approach is wrong. ${ }^{9}$

Bodde opens that essay by suggesting that the ancient Chinese myths and gods are different from the post-classical ones in that the ancient tradition lacks a developed "systematic mythology," and the individual myths are very "fragmentary and episodic." ${ }^{\prime 10}$ In the face of this absence, however, he warns us against the temptation to conclude erroneously that there were no myths in ancient China. Bodde wants to reconstruct China's ancient history which provides a clear example of euhemerization. He turns this process on its head in order to account for the absence of early archaic myths, and the presence of "historicized" and "humanized" accounts of the clan ancestors.

The theory to which Euhemerus has given his name maintains that the origin of myth is to be found in actual history, and that the gods and demigods of mythology were, to start with, actual human beings. As commonly used by writers on Chinese mythology, however, "euhemerization" denotes precisely the opposite process: the transformation of what were once myths and gods into seemingly authentic history and human beings. Unquestionably, a fair amount of what purports to be early Chinese history has been subjected to this kind of euhemerization ....."

Bodde quotes Henri Maspero who also reverses euhemerization by interpreting the process in terms of the stripping away of mythology, and the transforming of gods into sage emperors. ${ }^{12}$ Bodde goes on to criticize Bernhard Karlgren's proposal, in "Legends and Cults in Ancient China," that the Chou literature praises the ancients because of their ancestral heritage - the ancient sage emperors were clan ancestors, not gods or demigods. Karlgren is advocating the conventional understanding of euhemerization as a movement from actual historical events and persons to supernatural mythological events and gods, a position which explains the extant literature of ancient China. The predominant "this worldly" perspective together with the organismic world view and the overwhelming concern for historical record suggest that ancient Chinese culture heros were most likely actual historical ancestors, or a composite of the ancient lineage. In this debate I must join the side of Karlgren. Bodde's and Maspero's interpretations miss the mark - they lack the evidence needed to support their position. Their hypothesis of an ancient, but now lost, or at least, radically "historicized and humanized" mythology has no basis in the extant literature. Because they further propose that the early material was passed on in an oral tradition and was seriously revised before it was recorded, there is no way to substan- 
tiate their claim short of an archeological discovery of archaic mythology. At the same time, they have also created an unfalsifiable hypothesis. Fortunately their explanation is not the only available interpretation of ancient Chinese culture.

From the archeological discoveries of the archaic Shang and Chou material culture - the sacrificial vessels and oracle bones - and their extant literature, there is a stronger case to be made for an "ancestor veneration" basis for ancient Chinese religio-philosophy. ${ }^{13}$ The development of Chinese culture presents the possibility that systematic myth could develop as a cultural response after a people have lost their common roots in a shared ancestry, and so the various clans seek a common sense of purpose in systematizing their once disparate clan histories - the systematic myths make these people children of the same god, or supernatural culture hero, rather than a common ancestor. Hence, with the destruction of the feudal lords of the Chou, the destruction of the ancestral lineages and ancestral temples, the Han peoples developed a systematic mythology. Although this model might also apply to other cultures, as Euhemerus suggested, I would rather maintain a healthy pluralism of possible explanations of cultural development, given differences in geography and socio-economic factors, and so on.

The analysis of ancient myths might prove fruitful in the study of some cultures; however for the study of ancient China, archeology provides fertile ground for reconstructing the archaic tradition.

In the case of the archaic Shang dynasty, which was believed to be a mythical period before the excavation of its capital in the early 1920 s, the two predominant objects of material culture - the oracle bones and the bronze sacrificial vessels - reveal that the Shang royal family's socio-spiritual concerns focused on ancestor veneration. The oracle bones were primarily used to contact the deceased emperors, ancestors of the royal family, to petition them concerning weather conditions, prospects for the hunt, and impending dangers, sickness and military campaigns, especially attack at night. ${ }^{14}$ The bones were also used to keep records, and the excavation of a Shang bone "library" confirmed the traditional lineage given in the Shih chi (Records of the Historian), compiled in the early Han, of the Shang rulers, showing the accuracy of Chinese historical consciousness, especially concerning ancestral/dynastic lineage. Keep in mind that the traditional reckoning of "time" throughout the Chinese dynasties was according to the emperor's reign. The sacrificial bronze vessels are often inscribed with the name of the ancestor in 
whose honor the vessel was cast. The vessels were also used in ancestor veneration rituals, holding the delicacies and libations. Moreover, bronze sacrificial vessels were cast well into the Warring States period by feudal kings honoring even the earliest ancestors, like Huang Ti.

What we have in the case of archaic China is evidence of a royal family ancestor cult, where the actual deceased emperor is the composite embodiment of the dynastic lineage and viable heritage, but the ancestors are not beyond this world; they reside here among the living, and are contacted and revered through the rites and oracles. As the anthropologists Sarah Allan and Emily Ahern argue, Chinese gods are actually deceased ancestors. ${ }^{15}$ With increased and more complex economic and military contacts with other peoples, the historical, this-worldly perspective of the Shang was elaborated in the Chou with a plurality of ancestral lineages, possibly drawing on the various clan ancestor cults. Although the culture heros, such as Yao, Shun, Yü, and T'ang, are described as persons who sometimes perform near superhuman feats, or as inventing the artifacts of culture, nevertheless these are presented as natural historical events. As is evidenced in the extant literature, euhemerization was an ongoing process. It is especially after the fall of the grander houses of Chou that culture heros, and actual ancestors, are mythologized and deified. ${ }^{16}$

Following this second interpretation of archaic Chinese religiophilosophy grounded in a this-worldly clan ancestor cult, we can assert that China differs from Indo-European culture in its archaic and classical development. This difference means that one cannot access the archaic Shang world view solely through Chinese mythology. Instead we must turn to archeology. Where many of the world's archaic cultural myths present a cosmogony which elaborates their conception of time, in the case of archaic China, with its world-in-process perspective, cosmogony is decidedly absent. This absence is not given proper notice.

Regardless of the fact that the cosmogonic Pan Ku myth does not develop until the Han, many students of Chinese mythology begin their study with just such cosmogonic myths - certainly Bodde focuses on them, though he knows they are relatively late classical Han pieces. Chinese cosmogonic myths developed late in the classical period and give expression to the values of that time rather than the archaic period.

In his The Myth of the Eternal Return, Eliade has anachronistically found cosmogonic myths in archaic China. He attempts to reconstruct archaic religion and its understanding of "time" as a cosmic and ritual 
return to the cosmogonic origins. He summarizes this work succinctly in the Foreword written ten years after the third printing:

... it examines the fundamental concepts of archaic societies which although they are conscious of a certain form of "history," make every effort to disregard it. In studying these traditional societies, one characteristic has especially struck us: it is their revolt against historical time, their nostalgia for a periodical retum to the mythical time of the beginning of things, to the "Great Time."

His work supports this claim through a detailed study of ancient cultures and "pre-modern," "traditional" societies, what he calls contemporary "primitives." Drawing from a large source of materials, which he often uses in an historically and cross-culturally disjointed fashion, Eliade argues that archaic peoples made their lives meaningful by reenacting or imitating the "acts posited $a b$ origine by gods, heros, or ancestors," and that "reality is a function of the imitation of a celestial archetype."18

The problem with Eliade's analysis begins when, contrary to his own contention to guard against ethnocentrism, he asserts that the universal condition of archaic societies and religio-philosophy is represented by Plato. ${ }^{19}$ His generalization is that all archaic societies deny real history in their attempt to return to the celestial cosmogonic beginnings of "sacred time" (in illo tempore, ab origine). For Eliade, cosmogonic beginnings are a necessary condition of the archaic view of time. In discussing the regeneration of time, he states:

Thus we observe the immense importance that collective regeneration through repetition of the cosmogonic act acquired among the peoples who created history. ${ }^{20}$

Because Eliade has not studied an archaic society which lacks a cosmogony, he begs the question in assuming that cosmogony is a cross-cultural universal. He appears to be unaware of some archaic or so-called "primitive" societies such as the archaic Chinese and some Pacific Islanders that evidence a field process ontology, rather than the Platonic substance ontology. This oversight leads Eliade to overgeneralize in describing archaic ontologies.

This eternal return reveals an ontology uncontaminated by time and becoming. Just as the Greeks, in their myth of eternal retum, sought to satisfy their metaphysical thirst for the "ontic" and the static (for, from the point of view of the infinite, the becoming of things that perpetually revert to the same state is, as a result, implicitly annulled and it can even be affirmed that "the world stands still"), even so the primitive, by conferring a cyclic direction upon time, annuls its irreversibility. Everything begins over again at its commencement every instant. The past is but a prefiguration of the future. No event is irreversible and no transformation is final. In a certain sense, it is even possible to say 
that nothing new happens in the world, for everything is but the repetition of the same primordial archetypes; this repetition ... constantly maintains the world in the same auroral instant of the beginnings. Time but makes possible the appearance of things. It has no final influence upon their existence, since it is itself constantly regenerated. ${ }^{21}$

Without acknowledging the absence of cosmogony in archaic China and its distinctly this-worldly field ontology, Eliade has overlooked the possibility of a plurality of archaic ontologies, religio-philosophies, and world views.

Moreover, Eliade has overlooked the possibility that euhemerization or "mythicization of historical personages" might account for the development of archaic myth, even though he acknowledges this process at work in modern Yugoslavian epic. ${ }^{22}$ Douglas K. Wood provides an example of just how important the mythification of history can be by drawing from Nikolai Berdyaev's understanding of the philosophy of history.

According to Berdyaev, a philosophy of history is based not only upon a "religious metaphysic of history," but upon a mythological description of the historical process: "History is not an objective empirical datum; it is a myth."

For Berdyaev, we must examine both the religio-philosophical assumptions and the mythification of history to understand a philosophy of history. The "mythicization" of history would be crucial in understanding the archaic Shang conception of "time."

Another avenue of argument against these forms of "universalism" entails a reconstruction of archaic Shang and early Chou conceptions of shih (season/time). A study of the etymology, and cognates of shih, and its use in the early corpus, show that, generally speaking, the ancient Chinese conception of "time" is not tied up with a static ontology concerned with returning to the cosmogonic beginnings. ${ }^{24}$ For the majority of pre-Ch'in thinkers, "time" plays a crucial role in their understanding of the dynamic process cosmology such that "reality" or any other "form" or "thing" is only realized through its co-creative temporal relationships. Time is not a container of events, but "the critical time" which makes or breaks the constituting factors of an event or situation. "Time" is ontological.

The reconstruction of "time," "history," and "myth" in archaic Shang and Chou China might shed some light on and make clear the need to rethink our assumptions about Western culture.

University of Guam 


\section{NOTES}

1 Mircea Eliade, The Myth of the Eternal Return or, Cosmos and History, trans. Willard Trask (Princeton: Princeton University Press, 1974).

2 For instance, Henri Maspero, Wolfram Eberhard, Derk Bodde, Charles Le Blanc, but this is especially true of Mircea Eliade's student N. J. Girardot's work; Myth and Meaning in Early Taoism: The Theme of Chaos (hun-tun) (Berkeley: University of California Press, 1983). The cosmogonic approach is used in many of the anthologies on ancient mythology which may have influenced Bodde and Maspero to apply this approach in their interpretations of China.

David L. Hall has given an insightful critique of this paradigm in his, "Logos, Mythos, Chaos: Metaphysics as the Quest for Diversity," in New Essays in Metaphysics, ed. Robert Neville (Albany: State University of New York Press, 1986).

3 Frederick W. Mote has argued that China is unique in "having no creation myth"; see "The Cosmological Gulf Between China and the West," in Transition and Permanence: Chinese History and Culture, eds., David C. Buxbaum and F. W. Mote (Hong Kong: Cathay Press Limited, 1972), p. 7.

4 Clifford Geertz, "The Uses of Diversity," in The Tanner Lectures on Human Values, Vol. VII, ed. Sterling M. McMurrin (Salt Lake City: University of Utah Press, 1986), pp. 253-275.

5 John S. Mbiti, African Religions and Philosophy (New York: Anchor Books, 1970), p. 10.

6 Supra, note 2.

7 Frederick W. Mote, "The Cosmological Gulf Between China and the West," p. 7.

8 Charles Le Blanc, "A Re-examination of the Myth of Huang Ti," Journal of Chinese Religion, 13 \& 14 (1985-86), pp. 58-59.

9 Derk Bodde, "Myths of Ancient China," in Mythologies of the Ancient World, ed.,

S. N. Kramer (New York: Anchor Books, 1961), pp. 367-408.

10 Derk Bodde, "Myths of Ancient China," pp. 369-370.

11 Ibid., p. 372.

12 Henri Maspero, "Légendes mythologiques dans le Chou king," (1924) in Derk Bodde, "Myths of Ancient China," pp. 372-374.

13 Note that I use the expression "ancestor veneration" instead of the dated "ancestor worship" since the Chinese, and for that matter most peoples labeled as "ancestor worshipers" do not in actual practice "worship" their ancestors as, say, a Muslim worships Allah. The ancestors are respected and venerated as vital forces in the community. See Mbiti's rejection of the term "ancestor worship" in describing African religion, John S. Mbiti, African Religions and Philosophy, pp. 11-12.

I also use the term "religio-philosophy" because the classical Chinese traditions were primarily concemed with personal cultivation which was to effect a psycho-sociopolitical transformation. Moreover, the religious faith vs. philosophical reason dichotomy did not develop in China until Buddhism and other traditions introduced the distinction. Even then the faith vs. reason distinction did not take on the significance it did in Renaissance Europe.

14 Archaic Chinese ritual sacrifice and divination were both primarily directed toward the deceased royal ancestors, and these rituals petitioned for timely assistance and guidance 
from the ancestors, or the rituals venerated the ancestors' past achievements, and their continuing prowess in their posterity.

The archaic Chinese concern with divination reveals a great deal about their field processes ontology. First, the bulk of written material from the archaic Shang is inscribed on oracle bones, and second, the Book of Changes (I Ching), one of the oldest extant texts of the late Shang and early Chou, is a divination text. Chinese divination is not a fatalistic reading of a predetermined future, but rather Chinese divination is performed as a guide in making preparations for taking a proper course of action or refraining from an improper course of action in the future. Even the process of divination used in the archaic bone method displays this concern for manipulating the future outcome of events by making preparations for acting at the critical time.

Bone divination basically entailed a three-part process: first, a question was posed for divination, usually concerning the weather, illness, the hunt or warfare; second, the bone was cracked and the answer was read off the cracks, both question and answer were inscribed on the bone; and third, many times the result was also recorded. For example, the question would be asked about the success of the morrow's hunt; the divination would read "good luck"; and finally, the hunt's catch would be recorded. Chinese divination is programmatic in orientation. If good luck is divined, one knows to keep on the same track; if bad luck is divined, one knows to change one's approach. The focus of divination, then, is to give one guidance in achieving one's goals, for gaining insight into the need for change, and in making preparation for acting at the critical time.

It can and has been argued that the $I$ Ching reflects the shared presuppositions among rival philosophical traditions that made communication among them possible. Among these presuppositions, shih, time, can be singled out as integral to the central thematic: what is change? Shih plays an important role in the I Ching, and a sophisticated conception of shih yung (timely application) and shih chung (timeliness, hitting the mark in the harmony of seasonal timing) is developed in the I Ching, and especially its T'uan commentary.

is Sarah Allan, "Shang Foundations of Modern Chinese Folk Religion," in E. Ahem, Chinese Ritual and Politics (Cambridge: Cambridge University Press, 1981), p. 1 and 3.

16 Bernhard Karlgren, "Legends and Cults in Ancient China," Museum of Far Eastern Antiquities, Vol. 18 (1946), pp. 199-365.

17 Mircea Eliade, The Myth of the Eternal Return, p. ix.

18 Ibid., pp. 5-6.

19 "... Plato could be regarded as the outstanding philosopher of 'primitive mentality,' ..."lbid., p. 34.

20 Ibid., p. 75.

21 Ibid., pp. 89-90, italics added.

22 Ibid., p. 39.

23 Douglas K. Wood, Men Against Time (Laurence: University of Kansas Press, 1982), p. 50; citing Nikolai Berdyaev, The Meaning of History, trans. George Reavy (Cleveland: Living Age Books, 1962), p. 31.

${ }^{24}$ James D. Sellmann, Timeless and Sociopolitical Order in the Cii-shih ch' un-ch'iu (University of Hawaii: 1990), unpublished dissertation. 